\title{
SURFACE VELOCITY AND VARIATIONS OF OUTLET GLACIERS OF THE PATAGONIA ICEFIELDS BY MEANS OF TERRASAR-X
}

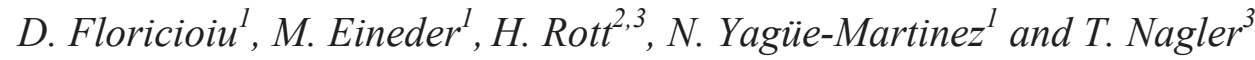 \\ ${ }^{1}$ DLR-IMF, Oberpfaffenhofen, Germany \\ ${ }^{2}$ Institut für Meteorologie und Geophysik, Universität Innsbruck, Austria \\ ${ }^{3}$ ENVEO IT, Innsbruck, Austria \\ E-mail: dana.floricioiu@dlr.de
}

\begin{abstract}
An incoherent amplitude correlation approach is used to derive ice motion fields of three major outlet glaciers of the Patagonia Icefields. High resolution repeat pass TerraSAR-X data of 2008 and 2009 were analyzed. The strong gradients in ice velocity of the terminus of San Rafael glacier, ranging from 2 to $16 \mathrm{~m} \mathrm{~d}^{-1}$, were captured well. Significant acceleration of the ice flow and losses in mass were observed for Upsala glacier.
\end{abstract}

Index Terms - TerraSAR-X, glacier velocity, Patagonia, feature tracking.

\section{INTRODUCTION}

The Patagonia icefields account for more than 60 percent of the Southern Hemisphere's glacial area outside of Antarctica. Accelerated retreat has been reported for the main outlet glaciers over the last three decades. Most of the glaciers are terminating with calving fronts. The frontal positions of calving glaciers are known to be related to various factors in addition to climate parameters, including bedrock morphology, calving depth and water temperature. Therefore observations of ice motion are of importance for the interpretation of glacier behavior. So far only few studies on glacier flow have been performed in this region, due to the difficult access to the glaciers and to the limited availability of suitable remote sensing data.

Previously, ice motion of several glaciers of the Patagonia Icefields was mapped with 24 hour repeat pass InSAR data, acquired at L-band during the space shuttle experiment SRL-2 in October 1994. ERS tandem InSAR analysis was possible only on few glaciers because the Cband data decorrelate due to adverse meteorological conditions and due to ice deformation at fast flowing glaciers.

The German TerraSAR-X satellite, launched in June 2007, provides an unprecedented opportunity to study the dynamics of the Patagonian glaciers. The X-band SAR data can be acquired in various modes with spatial resolutions ranging from 1 to $16 \mathrm{~m}$ with 11 days repeat pass orbits, rendering TerraSAR-X an instrument well suited for frequent mapping of rapidly moving outlet glaciers at high resolution.

\section{METHODOLOGY}

High resolution geocoded TerraSAR-X data were used to apply the amplitude correlation technique and to obtain two dimensional motion vector fields. Although generally the geometric phase (speckle) over ice and snow decorrelates during an orbit cycle of 11 days, the image cross-correlation of amplitude images can be employed for glacier surfaces where conservative surface features (drainage patterns, crevasses, etc.) are providing the needed image contrast. The correlation is performed on geocoded ground range pixels.

Fig. 1 shows a $256^{2}$ pixels patch of a repeat pass TerraSAR-X data pair over the crevassed terminus of San Rafael glacier. The correlation function in East (E) and North $(\mathrm{N})$ directions correspond to the pixel in the center of the patch. Significant changes at the ice surface lead to phase decorrelation and the correlation between image patches is low. For the reduction of incoherent speckle the image was block averaged by a factor of 4 before correlation. The peak width in the correlation function is $4 \times 6$ pixels in $\mathrm{E}$ and $\mathrm{N}$ direction, respectively. The feature displacement in 11 days is 26 pixels (E) x 24 pixels (N) An oversampling factor can be applied to the correlation function and a maximum correlation is obtained with subpixel accuracy: 25.94 pixels (E) x 24.44 pixels (N) resulting in an ice velocity of $16.2 \mathrm{~m} \mathrm{~d}^{-1}$.

The described technique is applied over equally distributed patches (template windows) on the entire SAR scene and a two dimensional motion vector field can be generated. The size of the searching, template (master) and matching (slave) windows are parameterized by the maximum ice velocity. Table 1 gives the parameter values used for the computations over the glaciers presented in Section 4. 


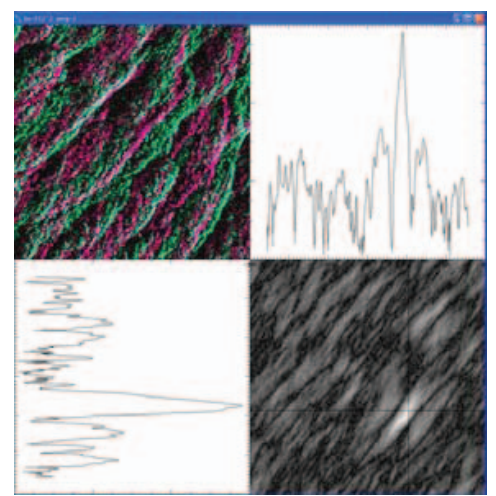

Fig. 1. Correlation function of a $256^{2}$ pixels patch of two TerraSAR-X images with 11 day interval over the crevassed terminus of San Rafael glacier. Upper left R/G composite of the two images. Lower right: Correlation function. Upper right: W-E cut. Lower left: N-S cut.

Table 1: Parameter values applied for the cross correlation method over the two investigated sites. The pixel size of the EEC SE product is $1.25 \mathrm{~m}$ and the time interval between the acquisitions is 11 days.

\begin{tabular}{|l|c|c|}
\hline $\begin{array}{l}\text { Feature tracking } \\
\text { parameter }\end{array}$ & $\begin{array}{c}\text { San Rafael \& } \\
\text { San Quintin }\end{array}$ & Upsala \\
\hline Max. velocity [m d ${ }^{-1}$ ] & 20 & 10 \\
\hline $\begin{array}{l}\text { Block averaging } \\
\text { factor }\end{array}$ & $4 \times 4$ & $2 \times 2$ \\
\hline Search size [pix] & \pm 44 & \pm 22 \\
\hline Min patch size [pix] & 128 & 128 \\
\hline Patch size [pix] & 256 & 256 \\
\hline Patch increment [pix] & 32 & 32 \\
\hline $\begin{array}{l}\text { Correlation window } \\
\text { size [pix] }\end{array}$ & 168 & 212 \\
\hline Oversampling factor & $2 \times 2$ & $2 \times 2$ \\
\hline
\end{tabular}

The absolute accuracy of the velocity estimates depends on several factors:

1. the atmospheric path delay variation between the two images (max. error $0.20 \mathrm{~m}$ in range)

2. orbit errors $(0.10 \mathrm{~m}$ in range and azimuth)

3. accuracy of the correlation approach (depending on the correlation window size)

Over one TerraSAR-X repeat cycle the overall absolute accuracy is governed by orbital errors and the atmosphere and is about $\operatorname{sqrt}(2 *(0.2 * 0.2+0.1 * 0.1)) / 11$ days $=0.030 \mathrm{~m}$ $\mathrm{d}^{-1}$ which is sufficient for many applications.

The relative accuracy for the individual motion vector for feature correlation depends on the correlation coefficient, the correlation patch size and the shape of the correlation function (feature pattern) [1].

\section{THE STUDY GLACIERS}

We investigate the ice motion on three glaciers of the Northern and Southern Patagonia Icefields (NPI and SPI).
San Rafael and San Quintin (Fig. 2) are main outlet glaciers of NPI covering together $38 \%$ of the NPI ice area. San Rafael $\left(46.7^{\circ} \mathrm{S}, 73.7^{\circ} \mathrm{W}\right)$ has an area of $722 \mathrm{~km}^{2}$ and is the only tidewater calving glacier of NPI. At the front the ice velocity reaches $17 \mathrm{~m} \mathrm{~d}^{-1}$ thus being one of the fastest non-surging glaciers in the world. The fast glacial flow is due to very high precipitation, topography and warm ice temperatures [2]. An area loss of $14 \mathrm{~km}^{2}$ between 1979 and 2001 was reported by [3].

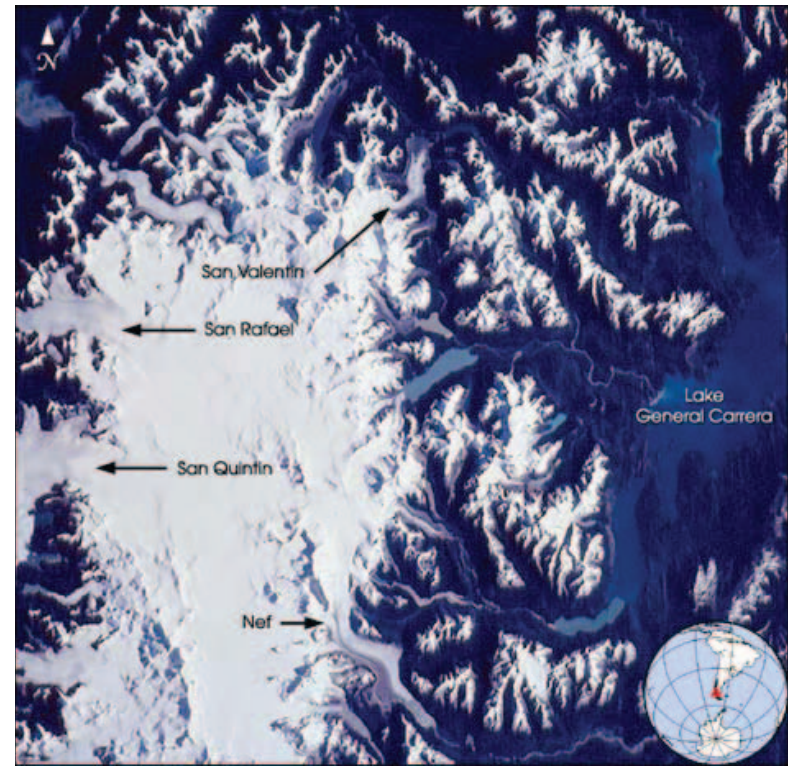

Fig. 2. The Northern Patagonia Icefield $\left(47^{\circ} \mathrm{S}, 73.5^{\circ} \mathrm{N}\right)$ and its main glaciers photographed from the space shuttle in December 2001.

San Quintin $\left(46.85^{\circ} \mathrm{S}, 73.7^{\circ} \mathrm{W}\right)$ covers $790 \mathrm{~km}^{2}$ and is the largest outlet glacier of NPI. In the period 1979 - 2001 San Quintin lost $33 \mathrm{~km}^{2}$ of its ice area.

In spite of some periods of advance experienced by both glaciers in the last decades, after 1999 they were retreating. This is the trend for all the NPI glaciers [3].

The velocity field of San Rafael was derived by [2] applying combined InSAR and amplitude correlation to L-band SIR-C data from 1994. At the calving front they estimated a velocity of $17.5 \mathrm{~m} \mathrm{~d}^{-1}$ consistent with earlier field estimates. For San Quintin no data set on ice velocity is available.

Upsala glacier $\left(49.7^{\circ} \mathrm{S}, 73.3^{\circ} \mathrm{W}\right)$ belongs to the SPI (Fig. 3) and has a surface of $902 \mathrm{~km}^{2}$. The glacier is receding since 1978 with several large scale calving events registered in the 80s and 90s. Between 1986 and 1997 the glacier lost $7.16 \mathrm{~km}^{2}$ in area and the front retreated by a maximum of $2.8 \mathrm{~km}$ [4]. Maximum velocities of $4.9 \mathrm{~m} \mathrm{~d}^{-1}$ were measured on Upsala in 1993 at stakes placed close to the front [5]. The ice velocity field of the entire terminus was derived with TerraSAR-X data from January 2008 [6]. Compared to the 1993 data an acceleration to $5.6 \mathrm{md}^{-1}$ at the stakes location was observed. 


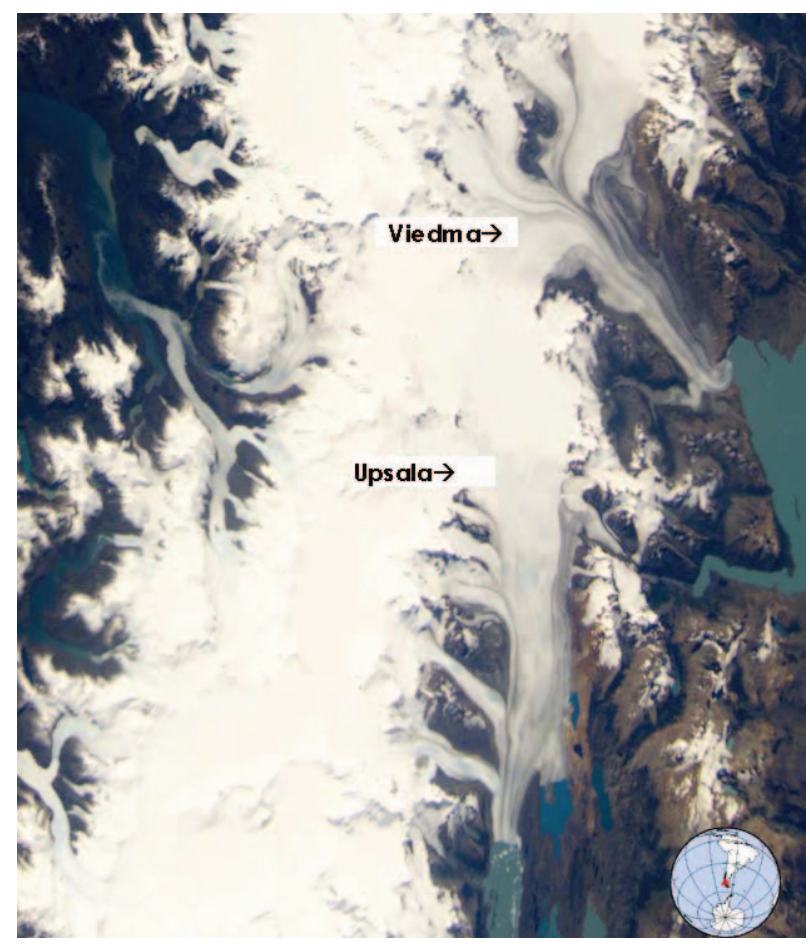

Fig. 3. ISS digital photography taken in January 2002 of a part of the Southern Patagonia Icefield showing the study glacier.

\section{GLACIER VELOCITY FIELDS}

The SAR amplitude correlation technique described in Section 2 was applied to TerraSAR-X data to map ice motion.

\subsection{San Rafael and San Quintin Glaciers}

One pair of repeat pass TerraSAR-X data was acquired in two consecutive 11-days cycles in January 2009. One stripmap TerraSAR-X scene $\left(30 \times 50 \mathrm{~km}^{2}\right)$ covers the termini of San Rafael and San Quintin glaciers (Fig. 4). While San Quintin has comparatively uniform surface velocities below $2 \mathrm{~m} \mathrm{~d}^{-1}$ all over the terminus, for San Rafael glacier large gradients can be observed. On the upper part the speed is about $2 \mathrm{~m} \mathrm{~d}^{-1}$. It increases downwards reaching $16.2 \mathrm{~m} \mathrm{~d}^{-1}$ at the front. This pattern can not be directly compared to the 1994 velocity field of [2] because here no high resolution information could be retrieved with InSAR. In 2009 the maximum velocity at the ice front is slightly slower than in 1994, but the front is not exactly at the same position. Overall, the velocity differences between the TerraSAR-X analysis in 2009 and previous investigations are rather small, suggesting that no major changes in the ice regime had occurred over the last two decades.

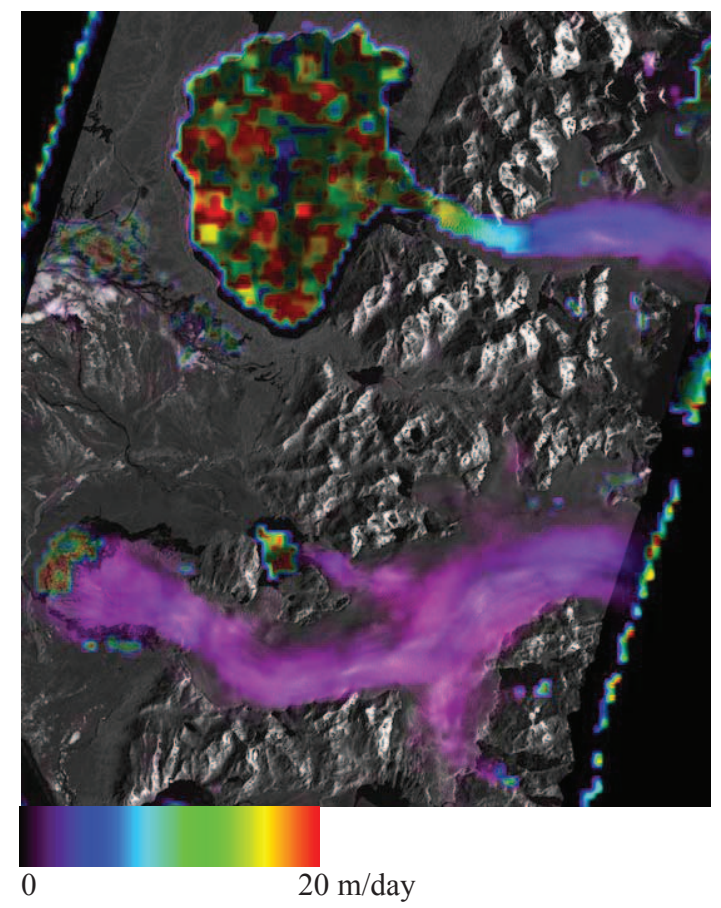

Fig. 4. Surface velocity at the terminus of San Rafael and San Quintin glaciers (NPI) in January 2009 superimposed on amplitude TerraSAR-X image.

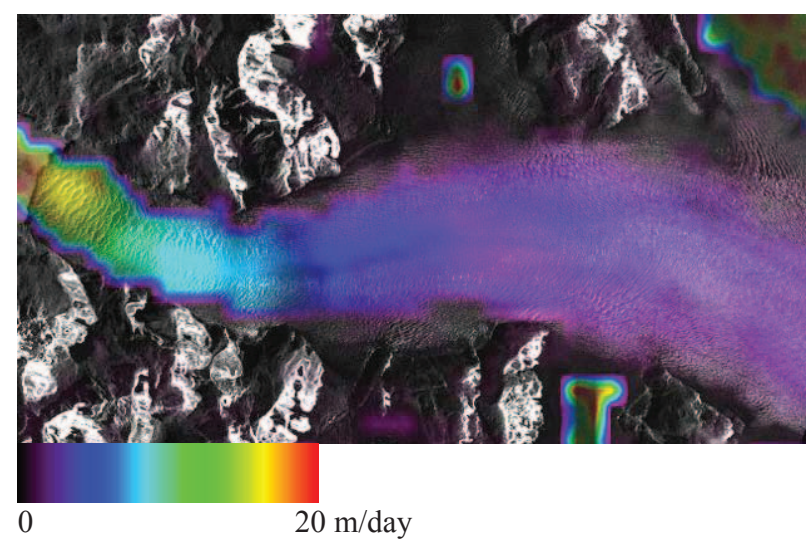

Fig. 5. Zoom of Fig. 4 on the last $14 \mathrm{~km}$ of the terminus of San Rafael glacier. Ice velocity in blue is $4.5 \mathrm{~m} \mathrm{~d}^{-1}$, in cyan $8 \mathrm{~m} \mathrm{~d}^{-1}$ and in yellow $14 \mathrm{~m} \mathrm{~d}^{-1}$.

\subsection{Upsala Glacier}

Three time series of TerraSAR-X data were acquired over Upsala glacier between January 2008 and May 2009. The derived frontal velocities show acceleration during this period: $5.6 \mathrm{~m} \mathrm{~d}^{-1}$ (Jan. 2008), $6.6 \mathrm{~m} \mathrm{~d}^{-1}$ (Oct. 2008) and $7.5 \mathrm{~m} \mathrm{~d}^{-1}$ (May 2009) (Fig. 6). The patchy pattern of the velocity field near the front suggests that these parts of the terminus are near floating condition or may even be floating. 


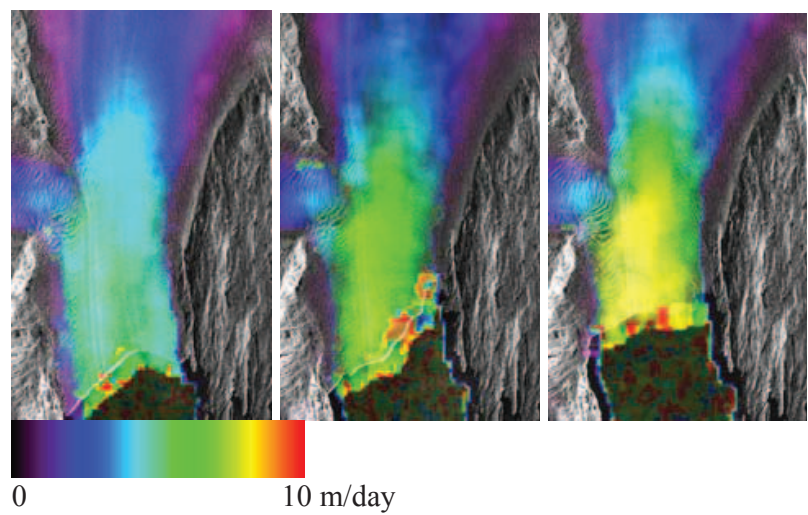

Fig. 6: Maps of surface ice velocity at the terminus of Upsala glacier in January 2008 (left), October 2008 (middle) and May 2009 (right).

In the same period the glacier terminus lost an area of about $4.3 \mathrm{~km}^{2}$ and the front retreated by about $1.7 \mathrm{~km}$ (Fig. 7). The TerraSAR-X images reveal a recent large scale calving event on Upsala glacier, similar to previous ones mentioned in the literature.

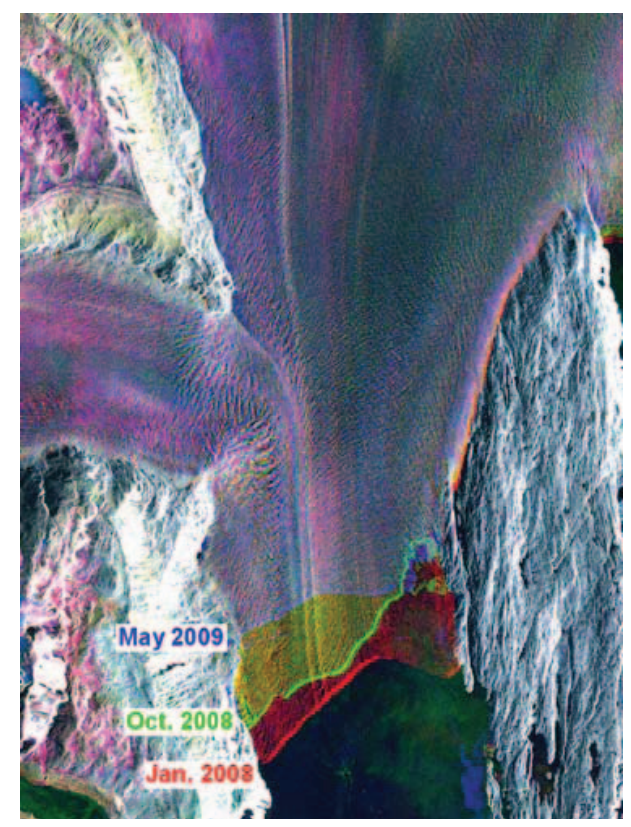

Fig. 7: Color composite of backscattering at the terminus of Upsala glacier showing the retreat of the glacier front between January 2008 and May 2009.

\section{CONCLUSION}

The studies on outlet glaciers of the Patagonia Icefield demonstrate the unique capabilities of TerraSAR-X for mapping and monitoring ice flow and deformation using image correlation techniques. The method was successfully applied on glaciers with different flow behavior ranging from San Rafael glacier, one of the fastest non-surging glaciers word wide, to San Quintin with rather moderate ice velocities. The observed recent retreat and acceleration at the front of Upsala glacier demonstrates the potential of TerraSAR-X to monitor short-term changes in glacier behavior.

\section{REFERENCES}

[1] R. Bamler, and M. Eineder, "Accuracy of Differential Shift Estimation by Correlation and Split Bandwidth Interferometry for Wideband and Delta-k SAR Systems", IEEE Geoscience and Remote Sensing Letters, vol. 2(2), pp. 151-155, 2005.

[2] E. Rignot et al, "Interferometric radar observations of Glaciar San Rafael, Chile", J. Glaciol, vol 42 (141), pp 279- 291, 1996.

[3] A. Rivera et al, "Ice elevation and areal changes of glaciers from the Northern Patagonia Icefield, Chile", Global and Planetary Change, vol. 59, pp. 126-137, 2007.

[4] M. Anyia et al, "Variations of Patagonian Glaciers, South America, utilizing RADARSAT Images", Proceedings of the International Symposium on RADARSAT Application Development and Research Opportunity (ADRO), Montreal, Canada 13-15 October 1998, CDROM, 1999.

[5] Skvarca, P., K. Satow, R. Naruse, and J.C. Leiva, "Recent thinning, retreat and flow of Upsala Glacier, Patagonia", Bulletin of Glacier Research, 13, pp 11-20, 1995.

[6] D. Floricioiu et al, "Velocities of major outlet glaciers of the Patagonia Icefield observed by TerraSAR-X", IEEE International Geoscience and Remote Sensing Symposium (IGARSS), Boston, 2008. 